\title{
Controls of Benthic Nitrogen Fixation and Primary Production from Nutrient Enrichment of Oligotrophic, Arctic Lakes
}

\author{
Gretchen M. Gettel, ${ }^{1,2 *}$ Anne E. Giblin, ${ }^{3}$ and Robert W. Howarth ${ }^{1,3}$
}

\begin{abstract}
${ }^{1}$ Department of Ecology and Evolutionary Biology, Cornell University, Ithaca, New York 14853, USA; ${ }^{2}$ Present address: UNESCO-IHE Institute of Water Education, 2611 AX Delft, The Netherlands; ${ }^{3}$ The Ecosystems Center, Marine Biological Laboratory, Woods Hole, Massachusetts 02543, USA
\end{abstract}

\begin{abstract}
We examined controls of benthic dinitrogen $\left(\mathrm{N}_{2}\right)$ fixation and primary production in oligotrophic lakes in Arctic Alaska, Toolik Field Station (Arctic Long-Term Ecological Research Site). Primary production in many oligotrophic lakes is limited by nitrogen $(\mathrm{N})$, and benthic processes are important for whole-lake function. Oligotrophic lakes are increasingly susceptible to low-level, non-point source nutrient inputs, yet the effects on benthic processes are not well understood. This study examines the results from a whole-lake fertilization experiment in which $\mathrm{N}$ and $\mathrm{P}$ were added at a relatively low level (4 times natural loading) in Redfield ratio to a shallow $(3 \mathrm{~m})$ and a deep $(20 \mathrm{~m})$ oligotrophic lake. The two lakes showed similar responses to fertilization: benthic primary production and respiration (each 50-150 $\mathrm{mg} \mathrm{C} \mathrm{m}^{-2}$ day $^{-1}$ )
\end{abstract}

Received 17 August 2012; accepted 18 June 2013;

published online 13 September 2013

Electronic supplementary material: The online version of this article (doi:10.1007/s10021-013-9701-0) contains supplementary material, which is available to authorized users.

Author Contributions: Gretchen M. Gettel conceived the research idea and sampling design. She performed the majority of the field and laboratory work, data analysis, and writing of the manuscript. Dr. Anne Giblin was involved in the original conception and funding of the whole-lake fertilization experiment, and she also contributed substantially to the research design, field work, writing, and interpretation of results. Dr. Robert W. Howarth contributed to the initial research ideas, methods development, and to the interpretation of results.

*Corresponding author; e-mail: g.gettel@unesco-ihe.org remained the same, and benthic $\mathrm{N}_{2}$ fixation declined by a factor of three- to fourfold by the second year of treatment (from $\sim 0.35$ to $0.1 \mathrm{mg} \mathrm{N} \mathrm{m}^{-2}$ day $^{-1}$ ). This showed that the response of benthic $\mathrm{N}_{2}$ fixation was de-coupled from the nutrient limitation status of benthic primary producers and raised questions about the mechanisms, which were examined in separate laboratory experiments. Bioassay experiments in intact cores also showed no response of benthic primary production to added $\mathrm{N}$ and $\mathrm{P}$, but contrasted with the whole-lake experiment in that $\mathrm{N}_{2}$ fixation did not respond to added N, either alone or in conjunction with P. This inconsistency was likely a result of nitrogenase activity of existing $\mathrm{N}_{2}$ fixers during the relative short duration ( 9 days) of the bioassay experiment. $\mathrm{N}_{2}$ fixation showed a positive saturating response when light was increased in the laboratory, but was not statistically related to ambient light level in the field, leading us to conclude that light limitation of the benthos from increasing water-column production was not important. Thus, increased $\mathrm{N}$ availability in the sediments through direct uptake likely caused a reduction in $\mathrm{N}_{2}$ fixation. These results show the capacity of the benthos in oligotrophic systems to buffer the whole-system response to nutrient addition by the apparent ability for significant nutrient uptake and the rapid decline in $\mathrm{N}_{2}$ fixation in response to added nutrients. Reduced benthic $\mathrm{N}_{2}$ fixation may be an early indicator of a eutrophication response of lakes 
which precedes the transition from benthic to water-column-dominated systems.

\section{INTRODUCTION}

Dinitrogen $\left(\mathrm{N}_{2}\right)$ fixation is one of the most important processes for understanding nutrient dynamics during the eutrophication of freshwater lakes. Our understanding has thus far focused on factors that control water-column $\mathrm{N}_{2}$ fixation and the role that it plays in compensating for $\mathrm{N}$ limitation of phytoplankton production in the presence of sufficient phosphorus supply (Schindler 1977; Smith 1983; Hendzel and others 1994). Benthic $\mathrm{N}_{2}$ fixation, however, may also be important to understanding lake eutrophication. This is especially true in the nutrient enrichment of oligotrophic lakes, which are commonly N-limited (for example, Elser and others 2009) and increasingly susceptible to atmospheric $\mathrm{N}$ deposition (for example, Bergström and Jansson 2006; Lepori and Keck 2012), climate change (especially thawing permafrost), and increasing catchment development (Hobbie and others 1999; Schindler and Smol 2006; Antoniades and others 2011).

In oligotrophic lakes, benthic production can dominate whole-lake production (Wetzel 1964; Ramlal and others 1994; Vadeboncoeur and others 2003; Ask and others 2009) and fuel whole-lake food webs (Sierszen and others 2003; Vander Zanden and others 2006; Hampton and others 2011). Although oligotrophic lakes can exhibit a high buffering capacity to added nutrients as oxic bottom-waters sequester phosphorus in the formation of iron-P oxides (Wetzel 2001; O'Brien and others 2005), the dynamics that affect benthic processes during the early stages of eutrophication can be subtle and evident even before water-column changes are documented (Rosenberger and others 2008). Detecting early changes is critical to the management of minimally impacted freshwaters threatened by non-point source pollution (Baron and others 2011). However, early changes in benthic production and benthic $\mathrm{N}_{2}$ fixation, especially in the context of low-level, non-point source nutrient inputs are not well understood.

The factors controlling benthic $\mathrm{N}_{2}$ fixation may differ from those of the pelagic (Howarth and others 1988a; Vitousek and others 2002). Current paradigm suggests that when primary production of phytoplankton is limited by $\mathrm{N}$ (typically with the molar ratio of available $\mathrm{N}: \mathrm{P}<16), \mathrm{N}_{2}$-fixing cyanobacteria growth is stimulated, and $\mathrm{N}_{2}$ fixation
Key words: benthic; nitrogen fixation; primary production; oligotrophic; Arctic; Toolik. compensates for N limitation (Schindler 1977; Schindler and others 2008). In benthic environments, light and sediment carbon content may also be important factors depending on the relative contribution of autotrophic and heterotrophic bacteria to the benthic $\mathrm{N}_{2}$ fixing community. Autotrophic cyanobacteria that fix $\mathrm{N}_{2}$ use light energy captured by photosynthesis, but oxygen created during photosynthesis can damage the nitrogenase enzyme (Postgate 1998). To deal with this constraint, $\mathrm{N}_{2}$ fixers may rely on stored carbon to fix $\mathrm{N}_{2}$ during periods of low light, or they may rely on recently synthesized carbon at high light levels to fuel $\mathrm{N}_{2}$ fixation in heterocysts that both protect the nitrogenase enzyme from oxygen and lack photosystem II (Postgate 1998). As a result of these strategies, the response of $\mathrm{N}_{2}$ fixation to increasing light in different environments is variable, ranging from saturating, linear, and inhibitory (Lewis and Levine 1984; Grimm and Petrone 1997; Higgins and others 2001). To date, few studies have examined the potential for light to limit the response of benthic $\mathrm{N}_{2}$ fixation to nutrient limitation.

Free-living autotrophic cyanobacteria and heterotrophic bacteria are the principle $\mathrm{N}_{2}$ fixers in the sediments of freshwater ecosystems, and both groups may be themselves nutrient and energy limited (Howarth and others 1988b; Vitousek and Howarth 1991). Free-living heterotrophic $\mathrm{N}_{2}$ fixers require a source of labile carbon, which in oligotrophic systems may be limiting (Howarth and others 1988a). Autotrophic $\mathrm{N}_{2}$ fixers also tend to have higher $P$ requirements than other members of the primary producer community for the construction of heterocysts (Postgate 1998; Vitousek and others 2002). Filamentous autotrophic $\mathrm{N}_{2}$ fixers may also require a source of inorganic $\mathrm{N}$ to stimulate photosynthesis and carbon transfer from the photosynthetic cells to the heterocyst (Vitousek and Howarth 1991). Chan and others (2004, 2006) showed that a sufficient energy supply is needed from photosynthetic cells before $\mathrm{N}_{2}$ fixation can occur, and this phenomenon could be evidenced by the fact that some nutrient addition experiments in oligotrophic systems have shown an inconsistent response of $\mathrm{N}_{2}$ fixation to added $\mathrm{N}$ and $\mathrm{P}$ (for example, Marcarelli and Wurtsbaugh 2007). The idea that $\mathrm{N}$ or $\mathrm{P}$ may limit $\mathrm{N}_{2}$ fixation in very oligotrophic systems has not been well evaluated but may help explain why compensatory $\mathrm{N}_{2}$ fixation 
does not alleviate $\mathrm{N}$ limitation in many oligotrophic lakes (for example, Elser and others 1990; Bergström and Jansson 2006; Elser and others 2009).

Although benthic processes are generally more important in oligotrophic systems than in more enriched systems, the response of benthic processes to nutrient enrichment is in part dependent upon lake geomorphology (Vadeboncoeur and others 2008). Shallow lakes, which also tend to be unstratified, may be buffered in the early stages of eutrophication due to strong interactions of the water column with the sediment, the high capacity of the sediments to take up nutrients (Alexander and others 1989; Nydick and others 2004a), and the sequestration of $P$ in sediments resulting from a well-mixed, oxic water column (O'Brien and others 2005). In contrast, deeper lakes (often stratified), have a lower portion of the water column interacting with the sediment and therefore may be dominated by a strong phytoplankton response, which shades the benthos and reduces benthic production (Vadeboncoeur and others, 2008). Like water-column $\mathrm{N}_{2}$ fixation, autotrophic benthic $\mathrm{N}_{2}$ fixation may respond positively to the addition of phosphorus, especially in shallow lake ecosystems where fixers may not be light limited. When light is limiting, heterotrophic $\mathrm{N}_{2}$ fixers may be able to compensate and respond positively in both deep and shallow lakes.

Nutrients and light as primary controls of $\mathrm{N}_{2}$ fixation are not particularly well explored in benthic ecosystems (Vitousek and others 2002). Furthermore, there are few studies that explore the dynamics between nutrient limitation of benthic primary production and compensatory $\mathrm{N}_{2}$ fixation, especially where lake morphology and light may play key roles. Therefore, the objective of this study was to examine the effects of nutrients and light on benthic $\mathrm{N}_{2}$ fixation and primary production in shallow and deep lakes at early stages of eutrophication. This was done in two ways: (1) Whole-lake experiments in which a relatively shallow $(3 \mathrm{~m})$ and a relatively deep $(20 \mathrm{~m})$ lake were fertilized with $\mathrm{N}$ and $\mathrm{P}$ at a relatively low loading rate and compared with similar-sized non-fertilized reference lakes; (2) Controlled laboratory experiments in which we manipulated nutrients and light in intact sediment cores to examine the mechanisms behind the responses we observed in the field.

\section{Methods}

\section{Site Description}

The study was carried out in four lakes near Toolik Field Station, Arctic Long-Term Ecological Research
(LTER) site in northern Alaska $\left(68^{\circ} 37^{\prime} \mathrm{N}, 149^{\circ} 35^{\prime} \mathrm{W}\right.$; Figure 1; Table 1). The fertilized lakes in this study are named "E" lakes, with E-5 being the deep fertilized lake and E-6 the shallow fertilized lake. The reference lakes are the "Fog" lakes, with Fog 2 being the deep reference lake and Fog 4 the shallow reference lake. These lakes are considered ultra-oligotrophic, with water-column ${ }^{14} \mathrm{C}$-primary production measurements ranging from 12 to $16 \mathrm{~g} \mathrm{C} \mathrm{m}^{-2} \mathrm{y}^{-1}$ (Miller and others 1986), and concentrations of ammonium, nitrate, and phosphate near analytical detection limit $(<0.1 \mu \mathrm{M}$ for all; Arctic LTER database). Lake E-5 is the deep fertilized lake and has a maximum depth of $12 \mathrm{~m}$ and a surface area of 1.3 ha (Table 1). The shallow fertilized lake, E-6, comprises two shallow basins that are divided by a rocky shoal. The maximum depth of each basin is 1.5 and $3 \mathrm{~m}$, respectively, and the surface area is 0.2 ha. The deep reference lake is Lake Fog 2, which has a maximum depth of $20 \mathrm{~m}$ and a surface area of 5.6 ha (Table 1). Lake Fog 4, the shallow reference lake, is similar in size to lake E-6 (0.19 ha) and has a simple basin with a maximum depth of $3 \mathrm{~m}$. The substrate differs among lakes at different depths. In both deep lakes, depths from 0 to $3 \mathrm{~m}$ comprises large rock cobble resulting from scouring of ice, which is $3 \mathrm{~m}$ thick in the winter. However, at those depths in the shallow lakes, soft peaty mud dominates. Below depths of $3 \mathrm{~m}$ in all the shallow and deep lakes, sediment comprises extremely fine-grained unconsolidated mud.

\section{Whole-Lake Fertilization}

The overall experimental design was to compare the responses of fertilized lakes to a pre-fertilized reference year (2000) and to two reference lakes in postfertilized years (2001-2004). Lakes E-5 and E-6 were fertilized by pumping a nutrient solution in a constant drip from a tethered floating raft from the center of each lake. $\mathrm{N}\left(\right.$ as $\left.\mathrm{NH}_{4} \mathrm{NO}_{3}\right)$ and $\mathrm{P}\left(\right.$ as $\left.\mathrm{H}_{3} \mathrm{PO}_{4}\right)$ were added in Redfield proportion (16:1 molar) for 42 days during summers 2001-2003. The target fertilization rate was $2.0 \mathrm{mmol} \mathrm{N} \mathrm{m} \mathrm{N}^{-3} \mathrm{y}^{-1}$ and $0.125 \mathrm{mmol} \mathrm{P} \mathrm{m} \mathrm{y}^{-3}$, or approximately 4 times the ambient $\mathrm{N}$ loading to Toolik Lake (Whalen and Cornwell 1985). To document the dynamics of the early stages of eutrophication, this rate is low relative to other studies (for example, Lake N-2, O'Brien and others 2005; Peter Lake, Vadeboncoeur and others 2001). In lake E-5, the fertilizer was applied on the basis of the volume of the epilimnion above the thermocline $(4 \mathrm{~m})$, which is $75 \%$ of total lake volume. Fertilization in shallow lake, E-6, was applied on the basis of its total volume. Rhodamine dye studies confirmed that mixing occurred before 


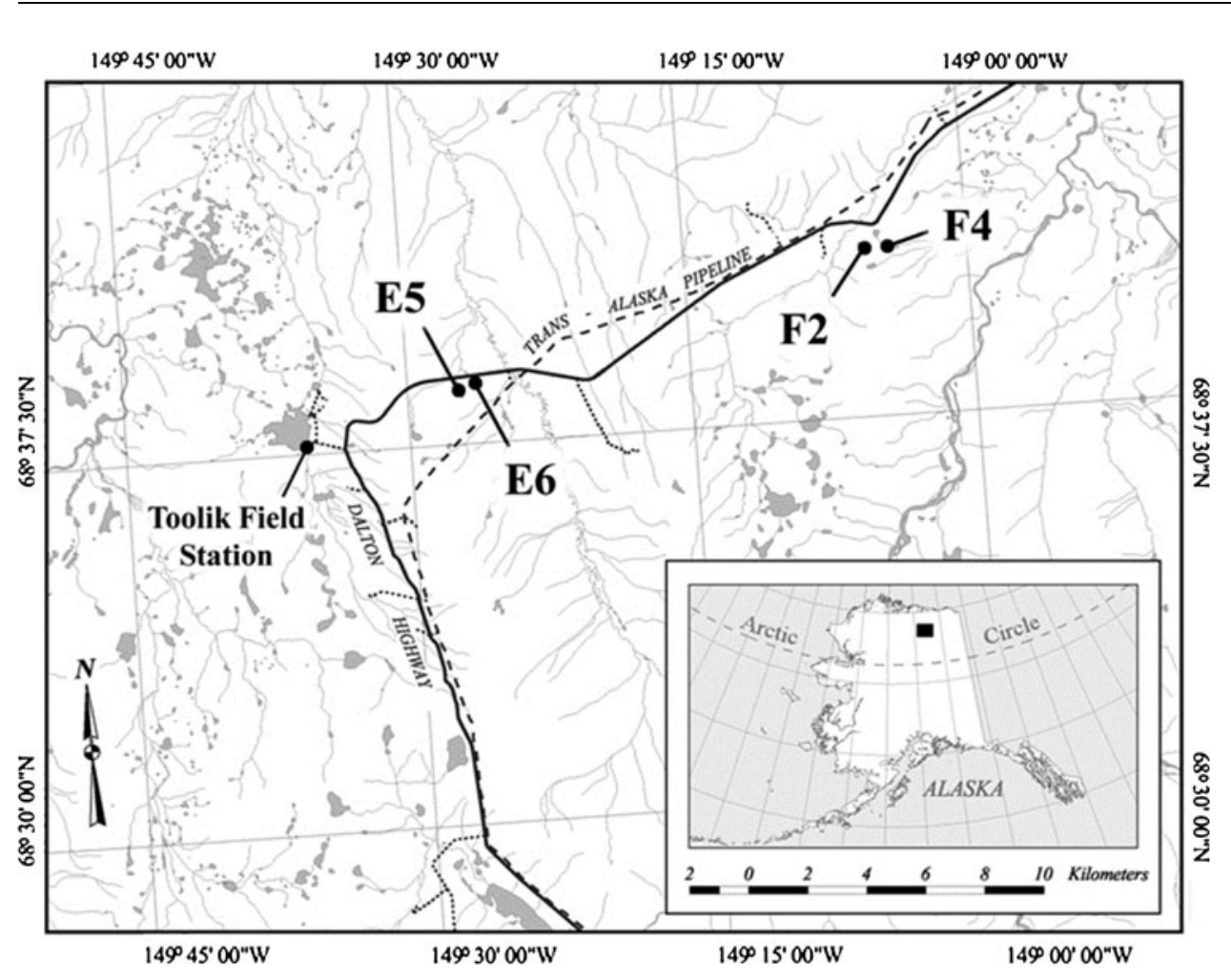

Figure 1. Map showing the location of deep and shallow fertilized lakes (E-5, and E-6. respectively) and the deep and shallow reference lakes (Fog 2 and Fog 4, respectively) relative to Toolik Field Station on the North Slope of Alaska, $68^{\circ} 37^{\prime} \mathrm{N}, 149^{\circ} 35^{\prime} \mathrm{W}$.

Table 1. Characteristics of Fertilized and Reference Lakes

\begin{tabular}{|c|c|c|c|c|}
\hline & \multicolumn{2}{|c|}{ Fertilized lakes } & \multicolumn{2}{|c|}{ Reference lakes } \\
\hline & E-5 (deep) & E-6 (shallow) & Fog 2 (deep) & Fog 4 (shallow) \\
\hline Maximum depth (m) & 12 & 3 & 20 & 3 \\
\hline Surface area (ha) & 1.3 & 0.2 & 5.6 & 0.19 \\
\hline Conductivity $\left(\mu \mathrm{S} \mathrm{s}^{-1}\right)$ & $7-12$ & $7-12$ & 150 & $90-120$ \\
\hline Chlorophyll $a\left(\mathrm{mg} \mathrm{l}^{-1}\right)$ & $0.3-5$ & $1-8$ & $0.5-8$ & $1.5-9$ \\
\hline $\mathrm{C}^{14}$ production $\left(\mathrm{mg} \mathrm{C} \mathrm{m}^{-3} \mathrm{day}^{-1}\right)$ & $0.28-70.5$ & $0.08-83.5$ & $0.16-5.7$ & $0.26-60.6$ \\
\hline
\end{tabular}

Values for conductivity, chlorophyll a and primary production represent range for weekly summer sampling (early May-mid-August) during the reference year (2000).

the fertilizer was washed out through outlet streams (George Kling, pers. comm.)

Benthic parameters including $\mathrm{N}_{2}$ fixation, primary production, respiration, and chlorophyll biomass (all described below) were measured three times per season in fertilized lakes except the prefertilization year (2000), when benthic processes were characterized once in mid-July (Table 2). The same sampling scheme was used in the reference lakes, except that, due to the logistical difficulties of accessing these more remote lakes with large chambers, benthic primary production was characterized once per season (Table 2), Measurements in all years were made at $3 \mathrm{~m}$ in lakes E-5 and Fog 2 and at $1.5 \mathrm{~m}$ and $2.5 \mathrm{~m}$ in E-6 and Fog 4, respectively. We established these "shallow" stations to sample similar mud substrates in all lakes, as cobble is dominant at $1-3$ depth in the deep lakes; furthermore, light availability at $3 \mathrm{~m}$ in the deep lakes was similar to light in the shallow lakes due to sediment re-suspension. Deep stations were added in 2002 and 2003 to examine the effect of light, as described below. These sampling stations are not meant to be used to scale measurements to whole-lake $\mathrm{N}_{2}$ fixation rates because logistical constraints prevented full benthic depth profiles and sampling cobble substrates; rather they are meant to assess controls on the dominant substratetype that can be compared across lakes.

\section{Rates of $\mathrm{N}_{2}$ Fixation}

SCUBA was used to collect five intact sediment cores at each sampling depth on each date. Core 
Table 2. The Number of Times Benthic Parameters were Sampled Per Summer Season in the Fertilized and Reference Lakes in Years 2000-2003

\begin{tabular}{|c|c|c|c|c|c|c|c|c|}
\hline \multirow[b]{2}{*}{ Year: } & \multicolumn{4}{|c|}{ Fertilized lakes } & \multicolumn{4}{|c|}{ Reference lakes } \\
\hline & 2000 & 2001 & 2002 & 2003 & 2000 & 2001 & 2002 & 2003 \\
\hline \multicolumn{9}{|l|}{ Shallow stations } \\
\hline $\mathrm{N}_{2}$ Fixation & 3 & 3 & 3 & 3 & 3 & 3 & 3 & 3 \\
\hline Chlorophyll & 1 & 3 & 3 & 3 & 1 & 3 & 3 & 3 \\
\hline GPP and ER & 1 & 3 & 3 & 3 & 1 & NA & 1 & 1 \\
\hline Water-column light profiles & 8 & 8 & 8 & 8 & 2 & 3 & 3 & 3 \\
\hline \multicolumn{9}{|l|}{ Deep stations } \\
\hline $\mathrm{N}_{2}$ Fixation & - & - & 3 & 3 & - & - & 3 & 3 \\
\hline
\end{tabular}

tubes were $30 \mathrm{~cm}$ tall, $9.75 \mathrm{~cm}$ in diameter, and contained about $10 \mathrm{~cm}$ of mud with an intact sediment-water interface and about 11 of overlying water. Cores were transported in a water-filled dark cooler to Toolik Field Station where measurements were made in an incubation facility with temperature and light control. We made measurements at ambient lake light and temperature conditions, which were measured at the time of sample collection. Ambient lake light and temperature, and hence incubation conditions, ranged between $2-150 \mu \mathrm{E} \mathrm{m}^{-2} \mathrm{~s}^{-1}$ and $6-13^{\circ} \mathrm{C}$, respectively, over the summer growing season.

$\mathrm{N}_{2}$ fixation was measured on three cores using the acetylene reduction assay (ARA), which quantifies the reduction of acetylene $\left(\mathrm{C}_{2} \mathrm{H}_{2}\right)$ to ethylene $\left(\mathrm{C}_{2} \mathrm{H}_{4}\right)$ by the nitrogenase enzyme (Hardy and others 1968). One core each was used to correct for ethylene production (Lee and Baker 1992) or consumption (Jackel and others 2004). Ethylene was rarely produced without the presence of acetylene, but rates corrected for ethylene consumption were linear and ranged from 5 to $15 \%$. These corrections did not change qualitative or statistical outcomes.

The ARA was conducted in the sediment core tubes, which also served as incubation chambers as detailed in Gettel and others (2007). Briefly, $100 \mathrm{ml}$ of water saturated with acetylene was added to the water overlying the mud surface following the procedure of Marino (2001) to reduce the ethylene blank. This resulted in a $10 \%$ acetylene solution. Each core had a gas headspace approximately $10 \%$ by volume of the water phase (Flett and others 1976), or about $100 \mathrm{ml}$. The gas phase was kept in equilibrium with the water phase by stir bars at the water-gas interface (see Gettel and others 2007 for details).

The total amount of ethylene present in the gas and water phase was determined using Henry's Law
(Flett and others 1976), and ethylene solubility was determined according a temperature-solubility relationship presented in Sander (1999). Ethylene samples were analyzed on a gas chromatograph using a Flame Ion Detector (FID) on a Shimadzu GC $8 \mathrm{~A}$ and a Porapak N column mesh size 80/100 (see Gettel and others 2007). Ethylene produced was converted to moles $\mathrm{N}_{2}$ fixed assuming a theoretical 3:1 conversion ratio, the value which is reasonably constrained for sediments that do not contain macrophytes (Howarth and others $1988 \mathrm{~b}$ reports a range 1.4-5.7). The very low rates of fixation precluded a calibration of the ratio using ${ }^{15} \mathrm{~N}$.

\section{Benthic Primary Production}

Benthic primary production and respiration in fertilized and reference lakes was estimated in situ by documenting the rate of oxygen consumption and production in opaque and transparent benthic chambers over 3-5 days. Benthic chambers (similar to those used by Sugai and Kipphut 1992) were deployed using ropes from the surface or by SCUBA divers. The chambers sank $2-4 \mathrm{~cm}$ into the mud bottom and enclosed $0.15 \mathrm{~m}^{2}$ of sediment with approximately $40 \mathrm{l}$ of overlaying water. The chambers had Tygon ${ }^{\circledR}$ tubes that were places on small floats to the surface which allowed for daily sampling of gasses and nutrients. Oxygen samples were collected once daily at similar times of day in BOD bottles, and measured using a Winkler titration. Ecosystem respiration (ER) was calculated as the rate (or slope) of $\mathrm{O}_{2}$ consumption in the dark chamber over the 3- to 5-day deployment. Gross primary production (GPP) was calculated as the rate of $\mathrm{O}_{2}$ production in the clear chamber + the rate of $\mathrm{O}_{2}$ consumption in the dark chamber. This method assumes that respiration that occurs in the light is equal to respiration in the dark and yields 
an average rate for the deployment period (Sugai and Kipphut 1992).

\section{Chlorophyll $a$ and Phaeophytin Analysis}

Three cores $2.7 \mathrm{~cm}$ in diameter were collected for chlorophyll $a$ and phaeophytin analysis at least three times per season in the fertilization years and once during the reference year. The top $2 \mathrm{~cm}$ of each core were sectioned and homogenized and a 5 -ml subsample was frozen at $-80^{\circ} \mathrm{C}$ for later chlorophyll analysis. Chlorophyll a samples were analyzed using acetone extraction (Lorenzen 1967). Because chlorophyll $a$ derived from sinking phytoplankton can degrade rapidly in the sediments (Bianchi and others 1991), we considered relative differences in benthic chlorophyll $a$ to be best expressed as a proportion of total chlorophyll (estimated as the sum of chlorophyll $a$ and phaeophytin). In each case, sampling date within each year was not significant $(P>0.05)$, so data were pooled for each year for subsequent analysis.

\section{Data Analysis for Whole-Lake Fertilization Experiment}

Benthic $\mathrm{N}_{2}$ fixation, primary production, and proportion chlorophyll $a$ were analyzed using a repeated measures ANOVA in Proc Mixed in SAS version 9.1. Proc Mixed accounts for unbalanced sampling design and allows for random effects as well as repeated measures. Treatment, lake (shallow, deep), year, and interactions among these variables were treated as fixed effects and accounted for random effects for each lake. We tested whether modeling covariance structure among repeated measures increased the overall model fit by examining the AIC value. In all cases, model fit was substantially improved by modeling covariance among repeated measures using a compound symmetrical structure that was specific for each lake. The most parsimonious model was developed by eliminating non-significant $(P>0.05)$ fixed effects one-by-one until the best model fit was determined. Data and model fit were checked for the assumption of normality, and because chlorophyll $a$ is expressed as proportion, these data were arcsin-square-root transformed. No other variables required transformation.

\section{Relating $\mathrm{N}_{2}$ Fixation to Light: Results from Whole-Lake Fertilization and Laboratory Incubations}

To examine the effects of light availability on $\mathrm{N}_{2}$ fixation rate, "deep" stations in E-5, E-6, and Fog 2 were sampled at 6-7 $\mathrm{m}$ and $2.5 \mathrm{~m}$, respectively, in 2002 and 2003. In Lake Fog 4 the maximum depth in that lake was already being sampled (Table 2). Ambient light was also measured in each lake throughout each summer and related to measurements of $\mathrm{N}_{2}$ fixation as described below.

Water-column profiles of photosynthetic active radiation (PAR) were measured weekly at $1 \mathrm{~m}$ intervals in the fertilized lakes and three times per season in the reference lakes using a LI-COR LI-192 underwater quantum sensor and corrected for ambient light using a LI-COR LI-190 quantum deck sensor. The light extinction coefficient, $k$, was calculated according to a non-linear decay model as described in Wetzel and Likens (1991) using SAS (2002).

A randomized coefficient analysis was performed to relate measurements of $\mathrm{N}_{2}$ fixation to ambient light measured on the day of sampling using Proc Mixed in SAS version 9.1 (2002). This analysis uses a mixed-model approach in regression analysis, much like the mixed-model ANOVA described above. Lake was treated as a random effect, and covariance structure among repeated measures was modeled using compound symmetric structure as described above. Light was transformed by natural $\log$ because the response of $\mathrm{N}_{2}$ fixation to light levels is not linear (see below).

In addition to relating measurements of $\mathrm{N}_{2}$ fixation to ambient light conditions, we also performed experiments in 2003 in which light was manipulated and $\mathrm{N}_{2}$ fixation measured in the incubation facility. These data were used to model $\mathrm{N}_{2}$ fixation-irradiance (NI) response curves. Three cores for the ARA and one core each for ethylene production and consumption were collected from 3 and $6 \mathrm{~m}$ depths in Fog 2 and E-5, and from 1 and $3 \mathrm{~m}$ depths in E-6, and from $2.5 \mathrm{~m}$ in Fog 4. Cores were first incubated in the dark $\left(0 \mu \mathrm{E} \mathrm{m}^{-2} \mathrm{~s}^{-1}\right)$ for $4 \mathrm{~h}$, and then at increasing light levels for $4 \mathrm{~h}$ at each light level for a total of 5 light levels up to $250-350 \mu \mathrm{E} \mathrm{m}^{-2} \mathrm{~s}^{-1}$. The highest light level is 5-6 times greater than ambient lake light levels. Using separate core sampling for all light treatments was not possible due to logistical constraints, but methods tests confirmed that $\mathrm{N}_{2}$ fixation rates were linear in each lake over long incubation times. In addition, the incubations were done from dark to light to reduce the possible effects of stored energy on $\mathrm{N}_{2}$ fixation rates.

The model used to fit the NI response curves was according to Stal and Walsby (2000), who used a Photosynthesis-Irradiance model from Webb and others (1974) to fit NI curves. Proc NLIN in SAS version 9.1 (2002) was used to estimate $N_{\max }, \alpha$, 
and $N_{\mathrm{d}}$ using $\mathrm{N}_{2}$ fixation and irradiance data according to:

$$
N_{\text {fix }}=N_{\max } *\left(1-\mathrm{e}_{\max }^{-\alpha I / \mathrm{N}}\right)+N_{\mathrm{d}}
$$

where $N_{\max }$ is the maximum $\mathrm{N}_{2}$ fixation rate achieved at saturation; $\alpha$ is the initial slope; $N_{\mathrm{d}}$ is the intercept, or $\mathrm{N}_{2}$ fixation in the dark, and $I$ is light (PAR) in $\mu \mathrm{E} \mathrm{m}^{-2} \mathrm{~s}^{-1}$. The half saturation constant $\left(K_{\mathrm{m}}\right)$ was calculated as:

$$
K_{\mathrm{m}}=\operatorname{Ln}(2) * N_{\max } / \alpha
$$

\section{$\mathrm{N}$ and P Fertilization to Intact Mud Cores}

To evaluate nutrient responses in the whole-lake fertilizations, a laboratory experiment was conducted in 2003 in which $\mathrm{N}$ and $\mathrm{P}$ were manipulated in intact cores collected from Fog 2. Twenty cores in total were collected from five different locations between 3 and $5 \mathrm{~m}$ depth. One core from each location was designated as Control, $+\mathrm{N}$, $+\mathrm{P}$, or $+\mathrm{N}+\mathrm{P}$ treatments, with five cores per treatment. Cores were fertilized in Redfield proportion with $\mathrm{N}$ as $\mathrm{NH}_{4} \mathrm{SO}_{4}$ at a rate of $1 \mu \mathrm{mol} \mathrm{l}^{-1}$ day $^{-1}$, and $\mathrm{P}$ as $\mathrm{KPO}_{4}$ at $0.0625 \mu \mathrm{mol} \mathrm{l}^{-1} \mathrm{day}^{-1}$. Cores were incubated at constant light $\left(180 \mu \mathrm{E} \mathrm{m}^{-2} \mathrm{~s}^{-1}\right)$ and temperature $\left(12^{\circ} \mathrm{C}\right)$ for 9 days, which was before core artifacts became visibly apparent. Measures of benthic metabolism (described below) were made on two cores from each treatment. These two cores were subsequently used as ethylene consumption and production blanks in the $\mathrm{N}_{2}$ fixation measurements. The remaining three cores were used for the ARA. Following benthic metabolism and $\mathrm{N}_{2}$ fixation measurements, one chlorophyll sample per core was taken as described above.

Data from the laboratory nutrient addition experiment were analyzed by one-way ANOVA and simple regression using Proc GLM in SAS version 9.1 (2002). Significant relationships were determined by using Tukey's post hoc test to correct for Type I error.

\section{Gross Primary Production and Respiration in Nutrient-Addition Cores}

In a manner similar to the ARA chambers, measures of production were made in intact sediment cores; however, in this case the chambers were filled completely with water. A logging $\mathrm{O}_{2}$ probe (WTW Oxi 340i) was placed into a water-filled port, and changes in oxygen consumption and production were recorded every 15 min over periods of dark and light, each lasting approximately $12 \mathrm{~h}$. Incubations were done at ambient lake tem- perature $\left(12^{\circ} \mathrm{C}\right)$ and light $\left(180 \mu \mathrm{E} \mathrm{m}^{-2} \mathrm{~s}^{-1}\right)$. ER was calculated as the rate of $\mathrm{O}_{2}$ consumption during the dark period of the incubation standardized to $24 \mathrm{~h}$. GPP was calculated as the rate of $\mathrm{O}_{2}$ production during the light period plus the amount of $\mathrm{O}_{2}$ consumed by ER. No correction was made for day length, as there are $24 \mathrm{~h}$ of light in an arctic summer day.

\section{Results}

\section{Whole-Lake Fertilizations}

In both the deep (E-5) and shallow (E-6) fertilized lakes, no differences were detected in benthic GPP and ER. In 2003, both GPP and ER appeared to increase in lake E- 6 by about 50\% (Figure 2; Appendix 1 in Supplementary Material); however, this effect is not statistically significant. Furthermore, no differences were evident between the pre- and postfertilization years. Regardless of treatment or year, the deep lakes had lower GPP than the shallow lakes, resulting in a significant lake effect (Appendix 2 in Supplementary Material). The shallow lakes also exhibited higher (that is, more negative) ER than deep lakes by about $40 \%$ regardless of treatment or year (Appendix 3 in Supplementary Material).

Benthic $\mathrm{N}_{2}$ fixation declined from the pre-fertilization year (2000) by about threefold in 2001, and continued to decline more gradually in each subsequent year (Figure 3; Appendix 1 in Supplementary Material). By the last year of measurement (2003), $\mathrm{N}_{2}$ fixation had declined by about $75 \%$ compared with 2000 . This resulted in a significant year effect in which 2000 was statistically different from years 2001 to 2003 (Appendix 3 in Supplementary Material). On average, benthic $\mathrm{N}_{2}$ fixation was depressed in the fertilized lakes relative to reference lakes by about fourfold, leading to a significant treatment effect (Appendix 2 in Supplementary Material). In contrast with fertilized lakes, the reference lakes showed no clear pattern in $\mathrm{N}_{2}$ fixation among years, and 2000 is within the range of variability of measurements made in the following years (Figure 3). In deep Fog 2, $\mathrm{N}_{2}$ fixation increased from 2000 to 2002 and declined in 2003. In shallow Fog 4, $\mathrm{N}_{2}$ fixation declined from 2000 to 2001 and increased throughout the remainder of the experiment.

Benthic chlorophyll $a$ biomass increased in E-5 and E-6 from 2000 to 2003 (Figure 4; Appendix 1 in Supplementary Material). Each fertilized lake had about twice as much chlorophyll $a$ in 2003 as it had in the pre-fertilization year but showed different response times. Chlorophyll $a$ biomass increased in E-6 each year following fertilization, 


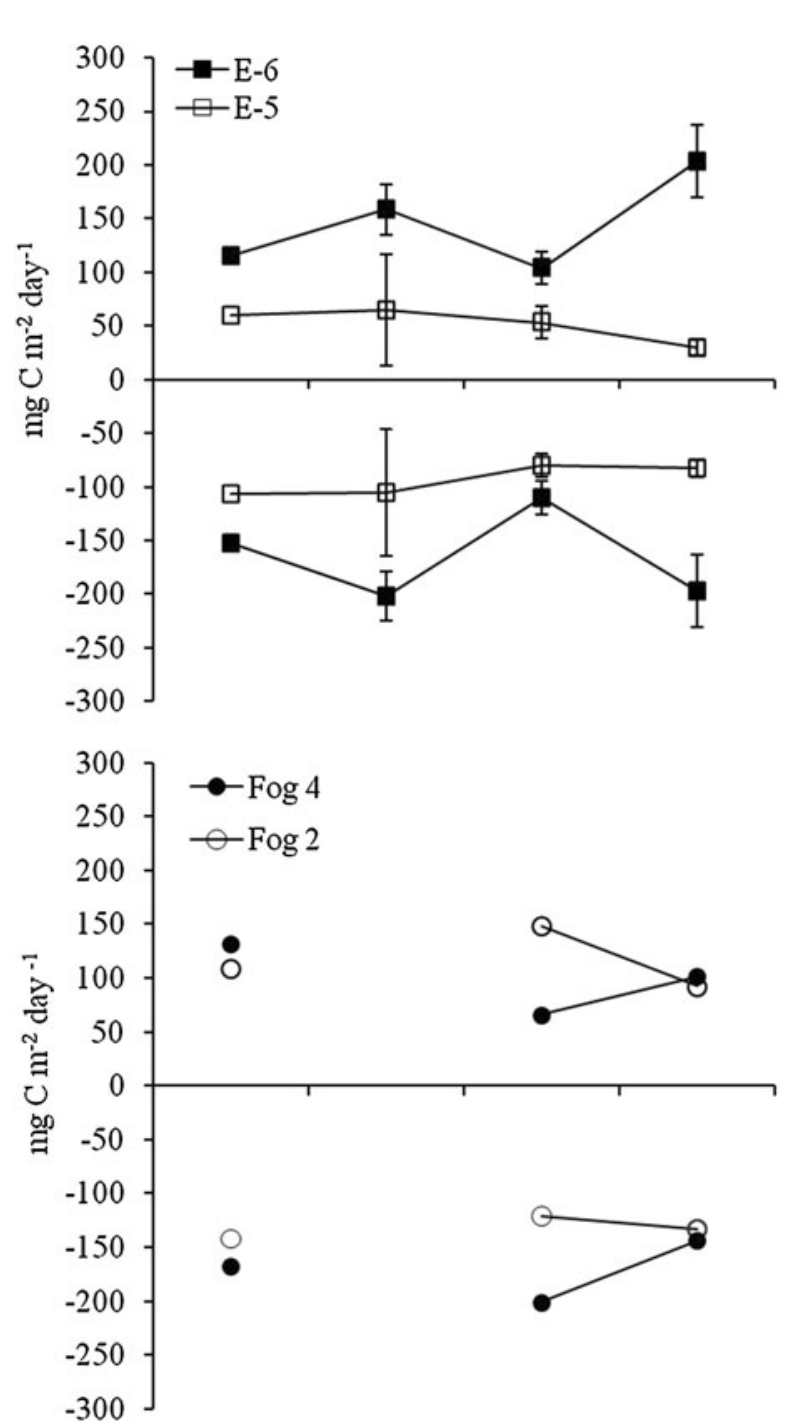

Figure 2. GPP (positive numbers) and ER (negative numbers) at shallow stations in the fertilized (top panel) and reference (bottom panel) lakes. Seasonal sampling within each year was not significant (ANOVA; $P>0.05$ ), so data were pooled for each year. GPP was significantly higher in the shallow lakes $(P<0.05)$, but there was no significant effect of fertilization or year in either GPP or ER (repeated measures ANOVA; $P>0.05$ ). No data are available from year 2001 from the reference lakes.

whereas chlorophyll in E-5 stayed constant until 2003 when it increased suddenly to similar levels as E-6. In reference lakes, chlorophyll $a$ biomass was more variable. Fog 2 showed no consistent yearly trend, and chlorophyll biomass in Fog 4 showed a similar pattern as $\mathrm{N}_{2}$ fixation, decreasing from 2000 to 2001 , and increasing from 2001 to 2003 . These patterns led to significant year and treatment effects (Appendix 2, 3 in Supplementary Material).
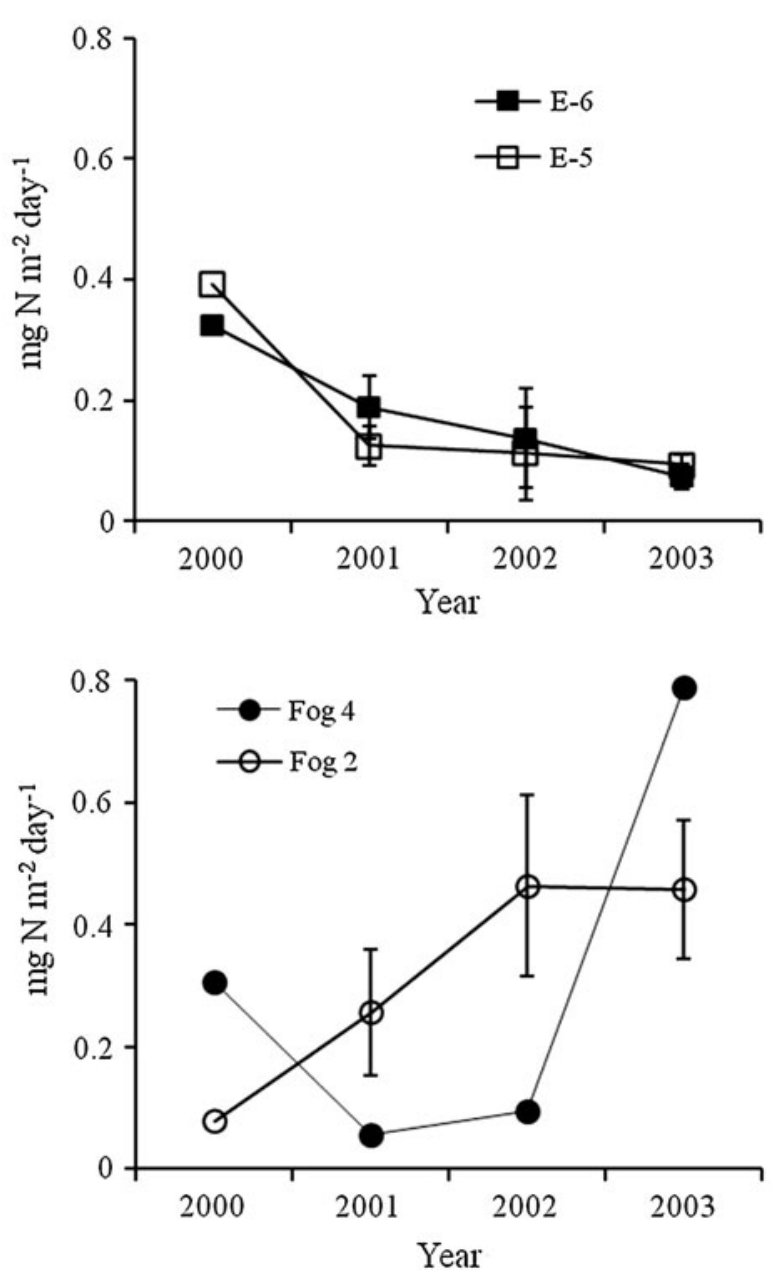

Figure 3. $\mathrm{N}_{2}$ fixation at shallow stations in the fertilized lakes (top panel) and the reference lakes (bottom panel). Seasonal sampling within each year was not significant (ANOVA; $P>0.05$ ), so data were pooled for each year. There was a significant effect of fertilization and year (repeated measures ANOVA; $P<0.05$ ) in which the reference year (2000) was higher than subsequent fertilized years.

\section{Response of $\mathrm{N}_{2}$ Fixation to Ambient Lake Light}

Ambient lake light is a function of both growing season PAR (Table 3A) and light extinction (Table $3 \mathrm{~B}$ ). Light extinction coefficients increased by the last year of treatment in the fertilized lakes (1.08-1.2 at $3 \mathrm{~m}$ in E-5, and $1.02-1.73$ in E-6, or $10-20 \%)$. There was variation in growing season PAR from year to year, and as a result ambient lake light did not change very much (Table $3 \mathrm{C}$ ). In lake E-6, light in the last year of the experiment was similar to the reference year, and in E-5, ambient lake light was reduced by about $26 \%$ (Table 3C). Notably, in the shallow reference lake (Fog 4), light 

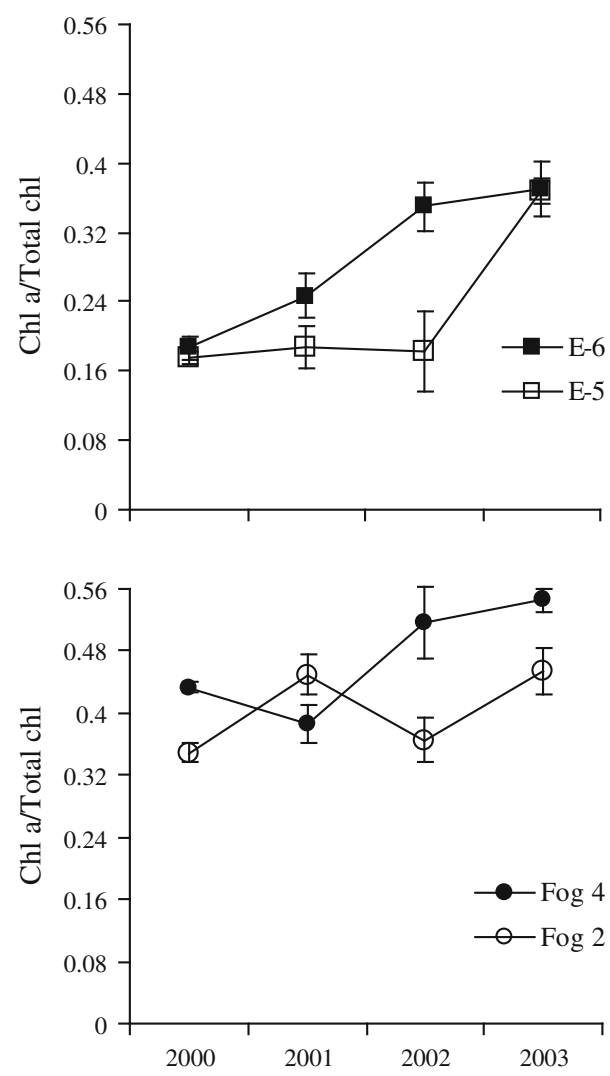

Figure 4. Annual averages of proportion of benthic chlorophyll $a$ at the shallow stations in the fertilized lakes (E-5 and E-6; top panel) and the two reference lakes (Fog 2 and Fog 4; bottom panel). Sampling date within each year was not significant $(P>0.05)$, so data were pooled for each year.

extinction increased (and ambient light decreased $\sim 75 \%$ ) due to sediment input from thermokarst (soil-slumping) activity on the adjacent bank.

A random-coefficient analysis relating ambient lake light data to $\mathrm{N}_{2}$ fixation rates in the fertilized and reference lakes showed that $\mathrm{N}_{2}$ fixation was not related to ambient light in E-5, E-6, or Fog 4 (Appendix 4 in Supplementary Material). The lack of relationship between ambient lake light and $\mathrm{N}_{2}$ fixation held true even though light extinction coefficients generally increased in fertilized lakes from the pre-fertilization year to 2003 (Table 3). Although light extinction increased in the shallow reference lake, Fog 4, $\mathrm{N}_{2}$ fixation was not related to ambient light either (Appendix 4 in Supplementary Material). $\mathrm{N}_{2}$ fixation was positively related to ambient lake light only in Fog 2, the clearest lake, which was responsible for the overall effect of light in the randomized coefficient analysis (Appendix 4 in Supplementary Material).

Shallow stations generally had higher $\mathrm{N}_{2}$ fixation rates than deep stations, and the fertilized lakes showed the largest difference between shallow and deep stations, which also showed the greatest difference in light availability (Table 3C). This pattern, however, was not a statistically robust difference in any of the treatment or reference lakes.

\section{$\mathrm{N}_{2}$ Fixation-Irradiance Curves}

In the controlled laboratory experiment in which $\mathrm{N}_{2}$ fixation was measured in response to increasing light levels, all of the shallow stations except E-6 showed a positive, saturating response (Figure 5; Table 4), and none of the deep stations showed a significant relationship, except in Fog 2. When no relationship with light was shown, the $\mathrm{N}_{2}$ fixation rates were also very low $\left(<0.15 \mathrm{mg} \mathrm{N} \mathrm{m}^{-2}\right.$ day $\left.^{-1}\right)$. The shallow station in Fog 2 had higher $N_{\max }$ than in E-5, but similar light efficiency $(\alpha)$ at low light levels. This resulted in a higher $I_{1 / 2}$ for Fog 2 (Table 4). The NI parameters for the Fog 2 shallow station were similar to the Fog 2 deep station whereas the deep station in E-5 showed no relationship with light. Comparing among shallow lakes, Fog 4 showed the lowest $\mathrm{N}_{\max }$ and $I_{1 / 2}$ of all the lakes, whereas E- 6 showed no relationship with light.

\section{Nutrient Addition to Cores}

In the nutrient-addition laboratory experiment, there was no effect of $\mathrm{N}$ either alone or together with $\mathrm{P}$. The benthic $\mathrm{N}_{2}$ fixation rate significantly increased due to the addition of $\mathrm{P}$ by $38 \%$ relative to the control. The $+\mathrm{P}$ treatment was also higher than the $+\mathrm{N}$ treatment by $46 \%$ (Figure 6; Appendix 5 in Supplementary Material). There was no significant response of GPP or chlorophyll $a$ to added nutrients, but there is a slight indication that GPP responded most to the $+\mathrm{N}$ treatments, and chlorophyll responded most to the $+\mathrm{N}+\mathrm{P}$ treatment (Figure 6).

\section{Discussion}

Benthic $\mathrm{N}_{2}$ fixation declined rapidly (in the first year of fertilization) and substantially (by a factor of three- to fourfold) in both the shallow and deep fertilized lakes (Figure 3). To our knowledge, there is only one other study that examines the effect of whole-lake fertilization on benthic $\mathrm{N}_{2}$ fixation, and it also showed a substantial decline $(50 \%)$ in benthic (eplithic) $\mathrm{N}_{2}$ fixation in response to fertilization with both N and P (Bergmann and Welsh 1990). This result is also consistent with previous studies in water-column environments that $\mathrm{N}_{2}$ fixation declines when the availability of $\mathrm{N}$ increases by external loading (for example, Schindler 1977). 
Table 3. Light Parameters for Reference and Treatment Lakes 2000-2003

\begin{tabular}{|c|c|c|c|c|c|c|c|}
\hline \multicolumn{8}{|c|}{ (A) Average growing season PAR $\left(\mu \mathrm{E} \mathrm{m}^{2} \mathrm{~s}^{-1}\right) \pm \mathrm{SE}^{1}$} \\
\hline 2000 & \multicolumn{7}{|c|}{$372 \pm 9.7$} \\
\hline 2001 & \multicolumn{7}{|c|}{$372 \pm 9.3$} \\
\hline 2002 & \multicolumn{7}{|c|}{$323 \pm 8.7$} \\
\hline 2003 & \multicolumn{7}{|c|}{$495 \pm 9.0$} \\
\hline & \multicolumn{2}{|c|}{$\mathrm{E}-5,3 \mathrm{~m}$} & \multicolumn{2}{|c|}{ Fog $2,3 \mathrm{~m}$} & \multicolumn{2}{|c|}{$\mathrm{E}-6,1 \mathrm{~m}$} & Fog $4,2.5 \mathrm{~m}$ \\
\hline \multicolumn{8}{|c|}{ (B) Average seasonal vertical extinction coefficient at depth ${ }^{2}$} \\
\hline 2000 & 1.1 & & \multicolumn{2}{|l|}{0.6} & \multicolumn{2}{|c|}{1.8} & 1.0 \\
\hline 2001 & 1.0 & & \multicolumn{2}{|l|}{0.4} & \multicolumn{2}{|l|}{1.6} & 1.2 \\
\hline 2002 & \multicolumn{2}{|l|}{1.3} & \multicolumn{2}{|l|}{0.4} & \multicolumn{2}{|l|}{2.2} & 1.3 \\
\hline \multirow[t]{3}{*}{2003} & \multicolumn{2}{|l|}{1.2} & \multicolumn{2}{|l|}{0.8} & \multicolumn{2}{|l|}{2.3} & 1.7 \\
\hline & \multicolumn{2}{|c|}{ Lake E-5 } & \multicolumn{2}{|c|}{ Lake Fog 2} & \multicolumn{2}{|c|}{ Lake E-6 } & Fog 4 \\
\hline & $3 \mathrm{~m}$ & $6 \mathrm{~m}$ & $3 \mathrm{~m}$ & $6 \mathrm{~m}$ & $1 \mathrm{~m}$ & $3 \mathrm{~m}$ & $2.5 \mathrm{~m}$ \\
\hline \multicolumn{8}{|c|}{ (C) Average summer PAR at depth $\left(\mu \mathrm{E} \mathrm{m} \mathrm{m}^{-2} \mathrm{~s}^{-1}\right)^{3}$} \\
\hline 2000 & 16.1 & - & 56.3 & - & 68.2 & - & 66.8 \\
\hline 2001 & 21.4 & - & 102.3 & - & 80.7 & - & 39.2 \\
\hline 2002 & 6.5 & 4.32 & 87.0 & 17.3 & 42.8 & 5.4 & 26.8 \\
\hline 2003 & 16.4 & 1.67 & 46.5 & 24.7 & 50.1 & 7.7 & 17.9 \\
\hline $\begin{array}{l}{ }^{1} \text { Ambien } \\
{ }^{2} \text { Vertical } \\
\text { reference } \\
{ }^{3} \text { Average }\end{array}$ & $\begin{array}{l}\text { ically a } \\
\text { fficient } \\
\text { lakes. }\end{array}$ & $\begin{array}{l}n(P A R, \\
\text { ach lak }\end{array}$ & $\begin{array}{l}\text { season }(21 \\
\text {. The vert }\end{array}$ & $\begin{array}{l}\text { g). } \\
\text { 1 coeffic }\end{array}$ & & oeffici & mpled depth in the \\
\hline
\end{tabular}
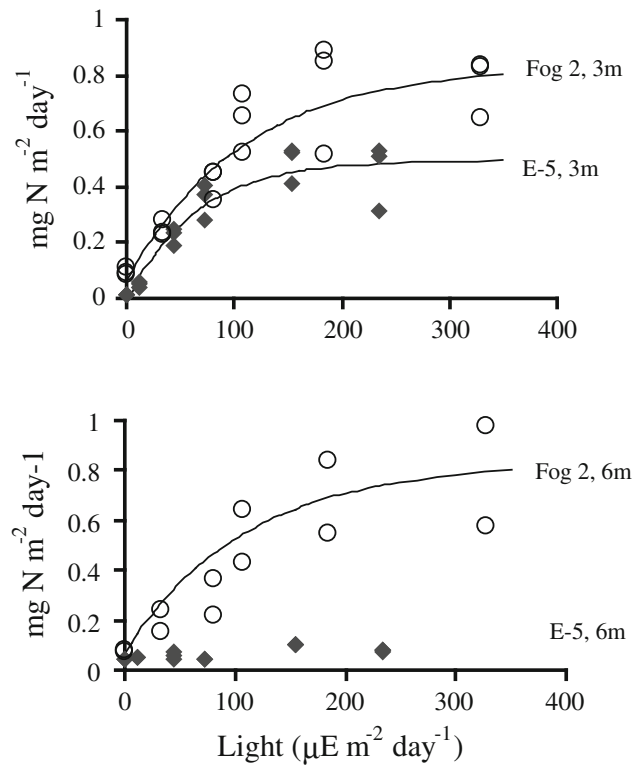

On first look, it appears that the mechanism behind the decline in benthic $\mathrm{N}_{2}$ fixation is similar to water-column $\mathrm{N}_{2}$ fixation, but this deserves further exploration. In the water column, $\mathrm{N}_{2}$ fixation is usually accompanied by an alleviation of $\mathrm{N}$ limitation and an increase in primary production (for example, Schindler and others 2008). In our case, we did not observe that GPP was strongly nutrient
Figure 5. Light response curves for benthic $\mathrm{N}_{2}$ fixation in the deep fertilized lake (E-5), the reference lake (Fog 2), the shallow fertilized lake (E-6), and the reference lake (Fog 4). Benthic $\mathrm{N}_{2}$ fixation in E-6 at $1.5 \mathrm{~m}$ and in E-5 at $6 \mathrm{~m}$ was not related to light level. limited (core incubation experiment; Figure 6), and GPP did not increase in response to fertilization in the whole-lake experiment (Figure 2). Although GPP was resistant to changes in nutrients, benthic $\mathrm{N}_{2}$ fixation declined rapidly. In contrast with water-column environments, the response of benthic $\mathrm{N}_{2}$ fixation to nutrient addition was disconnected from nutrient limitation status of benthic GPP. 
Table 4. Light Curve Parameters for Benthic $\mathrm{N}_{2}$ Fixation Curves from Shallow and Deep Stations in the Fertilized and Reference Lakes

\begin{tabular}{|c|c|c|c|c|c|c|c|c|}
\hline Lake & Depth (m) & Treatment & $N_{\max }$ & $\alpha$ & $N_{\mathrm{d}}$ & $I_{1 / 2}$ & $R^{2}$ & $p$ value \\
\hline E-5 & 3 & Ferti & 0.51 & 0.008 & $-0.012 \pm 0.08$ & 44.01 & 0.91 & \\
\hline Fog 2 & 3 & Reference & $0.77 \pm$ & $0.007 \pm$ & $0.067 \pm c$ & 76.08 & 0.86 & $<0.0001$ \\
\hline E-6 & 2 & Fertilized & NA & NA & NA & NA & NA & NA \\
\hline Fog 4 & 2.5 & Reference & $0.36=$ & $0.009 \pm 0$ & $-0.04 \pm$ & 27.76 & 0.53 & 0.001 \\
\hline E-5 & 6 & Fertilized & NA & NA & NA & NA & NA & NA \\
\hline Fog 2 & 6 & Reference & $0.87 \pm 0.22$ & $0.005 \pm 0.002$ & $0.05 \pm 0.09$ & 120.08 & 0.79 & 0.0008 \\
\hline
\end{tabular}

"NA" indicates that there was no significant relationship between light and benthic $N_{2}$ fixation.

\section{Benthic N Demand and N Availability}

The lack of response in GPP suggests that autotrophic $\mathrm{N}$ demand did not dramatically change through the course of fertilization. This demand must be met in a combination of new nutrient inputs through $\mathrm{N}_{2}$ fixation or fertilization and recycling. Consistent with current thinking, benthic $\mathrm{N}_{2}$ fixation probably declined as a result of increased supply of $\mathrm{N}$ either through direct uptake of fertilizer by the sediments or uptake of recycled $\mathrm{N}$ through mineralization. Several studies have shown that benthic communities have a substantial capacity for $\mathrm{N}$ uptake that can exceed that of phytoplankton communities in oligotrophic systems. In Castle Lake (California, USA), more than $50 \%$ of an added ${ }^{15} \mathrm{~N}-\mathrm{NO}_{3}$ tracer was taken up by sediments and periphyton, whereas less than $9 \%$ of it was recovered in the water column (Axler and Reuter 1996). Nydick and others (2004a) also showed that a significant portion of ${ }^{15} \mathrm{~N}-\mathrm{NO}_{3}$ tracer was taken up by sediments and periphyton in a mesocosm experiment in an oligotrophic lake in Wyoming (USA).

Water-column dynamics in this study also support the idea that added nutrients were directly taken up by the benthos. First, water-column concentrations of $\mathrm{N}$ and $\mathrm{P}$ remained near the analytical detection limit (Arctic LTER database; http:// ecosystems.mbl.edu/ARC/). Second, water column chlorophyll $a$ and primary production increases were not immediate and were also variable (Evans 2007). Both water column chlorophyll $a$ and primary production increased in the late summer by the third and fourth years of the experiment, but the response to fertilization was equally important as natural variation caused by storm (mixing) events (Evans 2007). This points to an interesting dynamic that at high fertilization rates, phytoplankton generally show a more consistent response than epipelic algae (Nydick and others 2004b), but at low fertilization rates, the benthos can play a dominant role, especially during the early stages of eutrophication. This conclusion was also reached by Rosenberger and others (2008) for oligotrophic lakes in the Pacific Northwest, USA.

Evidence of increased $\mathrm{N}$ availability through mineralization in the initial period of this study is not very strong. Changes in mineralization rates were not detectable through sediment respiration measurements, which also showed no change in response to added nutrients either in the fertilized lakes or in the laboratory (Figures 2, 6). However, more recent measurements in benthic dark chambers in situ show an increasing benthic ammonium flux, indicating that mineralization is starting to exceed heterotrophic $\mathrm{N}$ demand, and $\mathrm{N}$ availability is increasing the sediments (Giblin, unpublished data). Increased $\mathrm{N}$ availability - by direct uptake of $\mathrm{N}$ from added fertilizer at the start, and by through mineralization as eutrophication progresses-is the most likely cause of reduced $\mathrm{N}_{2}$ fixation in this study.

\section{$\mathrm{N}_{2}$ Fixation and Nutrient Limitation}

The independent response of benthic $\mathrm{N}_{2}$ fixation and GPP calls into question whether the $\mathrm{N}_{2}$ fixer community is limited by the same factors as the benthic autotrophic community (Scott and others, 2009). Potential limiting factors for the $\mathrm{N}_{2}$ fixers include organic matter for heterotrophic $\mathrm{N}_{2}$ fixers and $\mathrm{P}$ for filamentous autotrophic $\mathrm{N}_{2}$ fixers (Postgate 1998; Vitousek and others 2002). Evidence for a large contribution of heterotrophic $\mathrm{N}_{2}$ fixation would include high rates of $\mathrm{N}_{2}$ fixation in the dark, but data from the NI curves show dark rates are extremely low (Figure 5). Furthermore, low rates of sediment respiration relates to a low availability of labile organic matter. It remains to be seen whether $\mathrm{N}_{2}$-fixing heterotrophic bacteria will become more important through the course of eutrophication as sediment organic matter increases and light declines more drastically.

Autotrophic cyanobacteria are probably the most important $\mathrm{N}_{2}$ fixers in these lakes, where colonies 

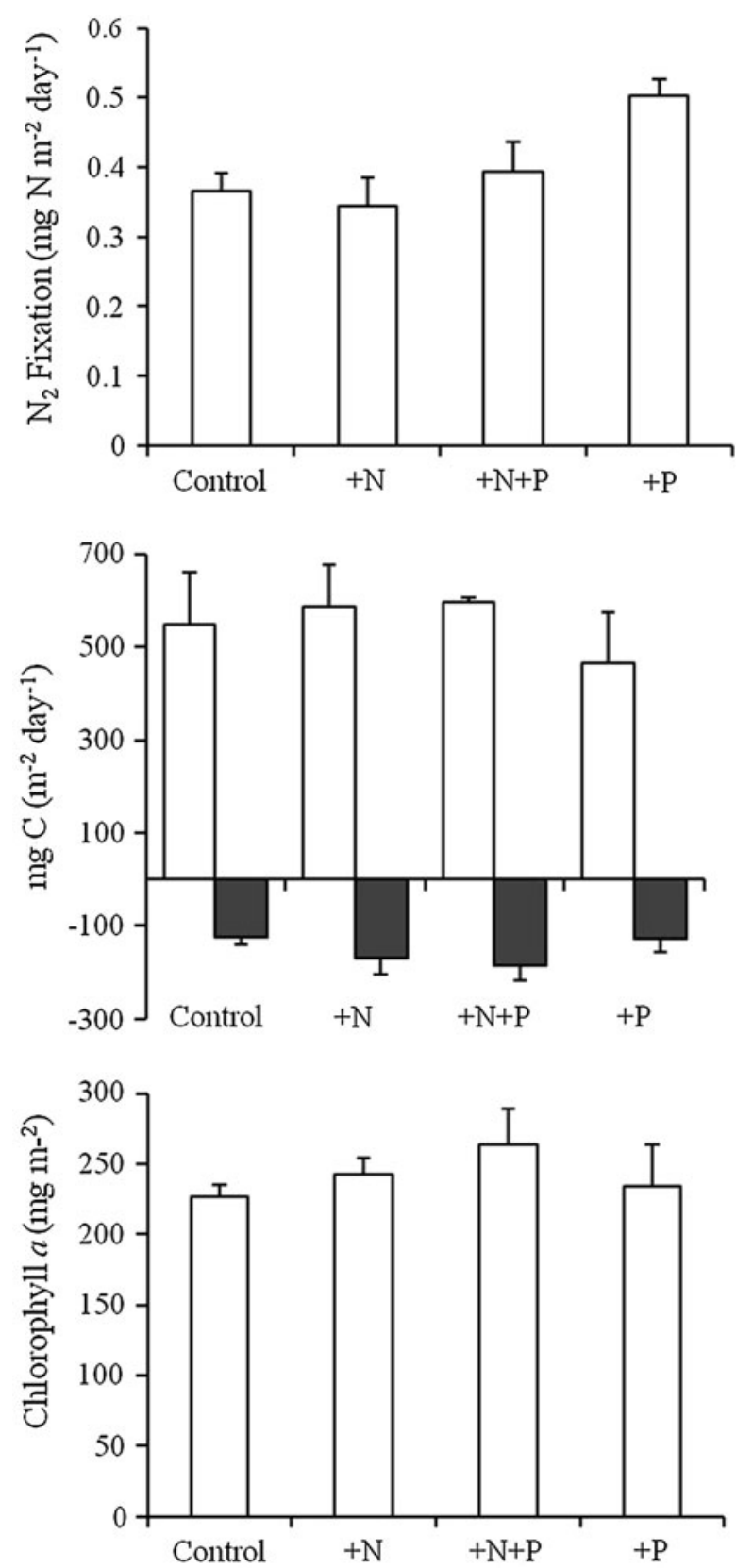

Figure 6. Results from a nutrient-addition experiment to intact sediment cores. $\mathrm{N}_{2}$ fixation in the $+\mathrm{P}$ treatment was significantly higher than the control and the $+\mathrm{N}$ treatment (Tukey; $\alpha<0.08$ ). Chlorophyll, GPP, and respiration were not significantly different among treatments.

of the autotrophic cyanobacterium, Nostoc sp., are commonly observed in the sediments (Gettel and others 2007). This makes the rapid decline in $\mathrm{N}_{2}$ fixation more puzzling because autotrophic $\mathrm{N}_{2}$ fixers tend to be slower growing and have longer turn-over rates than algal species (Howarth and others 1999; Vitousek and others 2002; Chan and others 2004, 2006). Heterocystous $\mathrm{N}_{2}$ fixing cyanobacteria have a higher $\mathrm{P}$ requirement (and therefore a lower $\mathrm{N}: \mathrm{P}$ ratio) than other autotrophs, and at low availability may be sensitive to P limitation. Our core incubation experiment showed that $\mathrm{N}_{2}$ fixation increased with the addition of $\mathrm{P}$ alone and did not respond to the addition of $\mathrm{N}$. The lack of response to $\mathrm{N}$ is probably a result of the existing nitrogenase, which continues to fix nitrogen even when $\mathrm{N}$ concentration is high (Howarth and others 1988a). The synthesis of new nitrogenase would likely be suppressed in response to increased $\mathrm{N}$ concentration over a longer incubation time (Howarth and others 1988a). Although we could not evaluate single nutrient limitation in the whole-lake fertilization experiment because $\mathrm{N}$ and $\mathrm{P}$ were both added, the subtle dynamics of differential limitation and the supply ratio of N:P could be important in the early stages of eutrophication of oligotrophic systems (Howarth and others 1988a; Vitousek and others 2002). With atmospheric deposition of $\mathrm{N}$ becoming an increasingly appreciated problem in oligotrophic lakes (Bergström and Jansson 2006; Lepori and Keck 2012), the factors that maintain $\mathrm{N}$ limitation-such as the possible $\mathrm{P}$ limitation of $\mathrm{N}_{2}$ fixers-deserves further research.

\section{Effect of Light on GPP and Chlorophyll $a$}

The effect of reduced light is another mechanism to explain the independent responses of $\mathrm{N}_{2}$ fixation and GPP. In principle, light limitation of GPP could prevent a full response of GPP to nutrient addition. Light extinction coefficients in this study declined only about $10-20 \%$ as a result of fertilization (Table 3). This result contrasts with those of a whole-lake fertilization experiment in Peter Lake, Michigan (USA), which showed an $\sim 75 \%$ decline in light availability to sediments due to increases in phytoplankton biomass and a corresponding decline in epipelic production (Vadeboncoeur and others 2001). Water column chlorophyll $a$ and primary production response was not as strong in our study (described above), and this discrepancy is probably as a result of the large difference in the fertilization rate, which was a magnitude greater in Peter Lake (4.7-23.5 $\mathrm{mM} \mathrm{P} \mathrm{m}^{-3} \mathrm{y}^{-1}$ vs. $0.125 \mathrm{mM} \mathrm{Pm}^{-3} \mathrm{y}^{-1}$ in this study).

Although GPP did not change, benthic chlorophyll $a$ concentration increased in the fertilized lakes (Figure 4). This is likely an early adaptation to reduced light through a reduced algal carbon to chlorophyll $a$ ratio (Wetzel 2001). This explains the lack of response in GPP and the increase in chlorophyll a concentration. This observation is corroborated by the shallow reference lake, Fog 4 
where thermokarst activity led to bank erosion on the shores, an increased sediment load, and a 75\% decrease in PAR (Table 3). Light reduction was apparently not sufficient to cause GPP to decline, but chlorophyll a concentration is another early signal of benthic response to eutrophication.

\section{Effect of Light on Benthic $\mathrm{N}_{2}$ Fixation}

The core experiments in the laboratory might also suggest on first look that reduced light may have also contributed to the decline in benthic $\mathrm{N}_{2}$ fixation. The NI curves show that benthic $\mathrm{N}_{2}$ fixation was positively related to light in three of the four lakes (Figure 5), which would support the idea of light limitation of $\mathrm{N}_{2}$ fixation. There is also evidence that $\mathrm{N}_{2}$ fixation is more light limited in the deep fertilization lake $(E-5)$ than in the deep reference lake (Fog 2), which is also consistent with the observation that lake E-5 experienced the greatest reduction in ambient light in response to fertilization (Table 3). The main adaption is that E-5 has a lower maximum potential $\left(N_{\max }\right)$ than Fog 2 , and as a result the $1 / 2$ saturation constant $\left(K_{\mathrm{m}}\right)$ is also lower.

Despite these early indications from the NI curves that $\mathrm{N}_{2}$ fixation is reacting to changing light conditions, the evidence for light limitation with in situ data is not very strong. Our data from the whole-lake measurements show that $\mathrm{N}_{2}$ fixation was not strongly controlled by ambient lake light in the fertilized lakes (Appendix 4 in Supplementary Material). This is probably because all lakes have a similar response (similar alpha; Table 3) to light. For example, at light levels observed in the lakes $\left(6-80 \mu \mathrm{E} \mathrm{m}^{-2} \mathrm{~s}^{-1}\right)$, both Fog 2 and E-5 have similar $\mathrm{N}_{2}$ fixation-irradiance efficiencies (similar $\alpha$ at $\alpha=0.007$ and 0.008 , respectively). The NI curves show that light is an important factor in affecting $\mathrm{N}_{2}$ fixation within lakes, but is not useful in predicting $\mathrm{N}_{2}$ fixation between lakes, because the other parameters $\left(N_{\max }\right.$ and $\left.K_{\mathrm{m}}\right)$ vary with respect to ambient light adaptation.

Other observations also support the lack of a light- $\mathrm{N}_{2}$ fixation relationship using the field data and ambient conditions. First, the greatest reduction in $\mathrm{N}_{2}$ fixation in the fertilized lakes occurred during the first year, when light availability was actually higher than in the pre-fertilization year (Table 3C). Second, Fog 4 experienced a much larger reduction in light availability than the fertilized lakes ( $\sim 75$ vs. $\sim 20 \%$ ), yet $\mathrm{N}_{2}$ fixation in that lake actually increased throughout the experiment. In conclusion, light was probably not a very strong factor affecting the decline of $\mathrm{N}_{2}$ fixation in these lakes relative to the additional $\mathrm{N}$ supply.

\section{ConCLUSION}

The results from this study show that benthic $\mathrm{N}_{2}$ fixation was substantially reduced in oligotrophic lakes receiving low levels of nutrient additions and that this reduction occurred independent of a response in benthic primary production. The effect of fertilization seems to significantly alter the source of new N input to support GPP before changes in GPP and other processes are evident. These results show the capacity of the benthos in oligotrophic systems to buffer whole-system response to nutrient addition by the apparent ability for significant nutrient uptake and the rapid decline in $\mathrm{N}_{2}$ fixation in response to added nutrients. Benthic $\mathrm{N}_{2}$ fixation may be an early indicator of a eutrophication response of lakes which precedes the transition from benthic to water-column-dominated systems.

\section{ACKNOWLEDGMENTS}

We thank Marcus Gay, Sam Kelsey, and Ian Washbourne who provided key diving support and helped with laboratory analyses. We are also grateful to Lyndon Valicenti, Daniel Steinburg, and Neil Bettez who were indispensable in the field and in the lab. Dr. Andrew Cooper assisted with statistical analysis. The Institute of Arctic Biology and VECO Polar Resources provided logistical support without which this work would not have been possible. Drs. Kenneth Irvine, Alex Flecker, and Nelson Hairston provided useful comments on this manuscript. This project was supported by NSF-OPP 9732281, NSF-DEB 9810222, NSF-DEB 0423385, and by a Doctoral Dissertation Improvement Grant NSF-DEB 0206173. Additional funding was provided by the Small Grants Program through the NSF-IGERT Program in Biogeochemistry and Environmental Change at Cornell University.

\section{OPEN ACCESS}

This article is distributed under the terms of the Creative Commons Attribution License which permits any use, distribution, and reproduction in any medium, provided the original author(s) and the source are credited.

\section{REFERENCES}

Alexander V, Whalen SC, Klingensmith KM. 1989. Nitrogen cycling in arctic lakes and ponds. Hydrobiologia 172:165-72.

Antoniades D, Michelutti N, Quinlan R, Blais JM, Bonilla S, Douglas MSV, Pienitz R, Smol JP, Vincent WF. 2011. Cultural eutrophication, anoxia, and ecosystem recovery in Meretta Lake, high arctic Canada. Limnol Oceanogr 56:639-50. 
Ask J, Karlsson J, Persson L, Ask P, Bystrom P, Jansson M. 2009. Whole-lake estimates of carbon flux through algae and bacteria in benthic and pelagic habitats of clear-water lakes. Ecology 90:1923-32.

Axler RP, Reuter JE. 1996. Nitrate uptake by phytoplankton and periphyton: whole-lake enrichments and mesocosm $\mathrm{N}_{15}$ experiments in an oligotrophic lake. Limnol Oceanogr 41:659-71.

Baron JS, Driscoll CT, Stoddard JL, Richer EE. 2011. Empirical critical loads of atmospheric nitrogen deposition for nutrient enrichment and acidification of sensitive U.S. Lakes. Bioscience 61:602-13.

Bergmann MA, Welch HE. 1990. Nitrogen fixation by epilithic periphtyon in small arctic lakes in response to experimental nitrogen and phosphorus fertilization. Can J Fish Aquat Sci 47:1545-50

Bergström AK, Jansson M. 2006. Atmospheric nitrogen deposition has caused nitrogen enrichment and eutrophication of lakes in the northern hemisphere. Glob Change Biol 12:63543.

Bianchi TS, Findlay S, Fontvieille D. 1991. Experimental degradation of plant materials in Hudson River sediments. 1. Heterotrophic transformations of plant pigments. Biogeochemistry 12:171-87.

Chan F, Pace ML, Howarth RW, Marino RM. 2004. Bloom formation in heterocystic nitrogen-fixing cyanobacteria: the dependence on colony size and zooplankton grazing. Limnol Oceanogr 49:2171-8.

Chan F, Marino RL, Howarth RW, Pace ML. 2006. Ecological constraints on planktonic nitrogen fixation in saline estuaries. II. Grazing controls on cyanobacterial population dynamics. Mar Ecol Prog Ser 309:41-53.

Elser JJ, Marzolf ER, Goldman CR. 1990. Phosphorus and nitrogen limitation of phytoplankton growth in the fresh waters of North America: a review and critique of experimental enrichments. Can J Fish Aquat Sci 47:1468-77.

Elser JJ, Kyle M, Steger L, Nydick KR, Baron JS. 2009. Nutrient availability and phytoplankton nutrient limitation across a gradient of atmospheric nitrogen deposition. Ecology 90:3062-73.

Evans MA. 2007. Ph.D. Thesis. Phytoplankton ecology of arctic lakes. University of Michigan 248p.

Flett RJ, Hamilton RD, Campbell NE. 1976. Aquatic acetylenereduction techniques: solutions to several problems. Can J Microbiol 22:43-51.

Gettel GM, Giblin AE, Howarth RW. 2007. The effects of grazing by the snail, Lymnaea elodes, on benthic $\mathrm{N}_{2}$ fixation and primary production in oligotrophic, arctic lakes. Limnol Oceanogr 52:2398-409.

Grimm NB, Petrone KC. 1997. Nitrogen fixation in a desert stream ecosystem. Biogeochemistry 37:33-61.

Hampton SE, Fradkin SC, Leavitt PR, Rosenberger EE. 2011. Disproportionate importance of nearshore habitat for the food web of a deep oligotrophic lake. Mar Freshw Res 62:350-8.

Hardy RWF, Holsten RD, Jackson EK, Burns RC. 1968. Acetylene-ethylene assay for $\mathrm{N}_{2}$ fixation: laboratory and field evaluation. Plant Physiol 43:1185-207.

Hendzel LL, Hecky RE, Findlay DL. 1994. Recent changes of $\mathrm{N}_{2}$ fixation in Lake 227 in response to reduction of the N/P loading ratio. Can J Fish Aquat Sci 51:2247-53.

Higgins SN, Hecky RE, Taylor WD. 2001. Epilithic nitrogen fixation in the rocky littoral zones of Lake Malawi, Africa. Limnol Oceanogr 46:976-82.
Hobbie JE, Peterson BJ, Bettez N, Deegan L, O'Brien WJ, Kling GW, Kipphut GW, Bowden WB, Hershey AE. 1999. Impact of global change on the biogeochemistry and ecology of an arctic freshwater system. Polar Res 18:207-14.

Howarth RW, Marino R, Cole JJ. 1988a. Nitrogen fixation in fresh water, estuarine, and marine ecosystems. 2. Biogeochemical controls. Limnol Oceanogr 33:688-701.

Howarth RW, Marino R, Lane J, Cole JJ. 1988b. Nitrogen fixation in fresh water, estuarine, and marine ecosystems. 1. Rates and importance. Limnol Oceanogr 33:669-87.

Howarth RW, Chan F, Marino R. 1999. Do top-down and bottom-up controls interact to exclude nitrogen-fixing cyanobacteria from the plankton of estuaries? An exploration with a simulation model. Biogeochemistry 46:203-31.

Jackel U, Schnell S, Conrad R. 2004. Microbial ethylene production and inhibition of methanotrophic activity in a deciduous forest soil. Soil Biol Biochem 36:835-40.

Lee RF, Baker J. 1992. Ethylene and ethane production in an estuarine river: formation from the decomposition of polyunsaturated fatty-acids. Mar Chem 38:25-36.

Lepori F, Keck F. 2012. Effects of atmospheric nitrogen deposition on remote freshwater ecosystems. Ambio 41:235-46.

Lewis WM, Levine SN. 1984. The light response of nitrogen fixation in Lake Valencia, Venezuela. Limnol Oceanogr 29:894-900.

Lorenzen CJ. 1967. Determination of chlorophyll and pheopigments: spectrophotometric equations. Limnol Oceanogr $12: 343-6$

Marcarelli AM, Wurtsbaugh WA. 2007. Effects of upstream lakes and nutrient limitation on periphytic biomass and nitrogen fixation in oligotrophic, subalpine streams. Freshw Biol $52: 2211-25$.

Marino RM. 2001. An experimental study of the role of phosphorus, molybdenum, and grazing as interacting controls on planktonic nitrogen fixation in estuaries. Ph.D. Thesis, Cornell University. 199 pp.

Miller MC, Hater GR, Spatt P, Westlake P, Yeakel D. 1986. Primary production and its control in Toolik Lake, Alaska. Archiv für Hydrobiologie Supplement 74:97-131.

Nydick KR, Lafrancois BM, Baron JS. 2004a. $\mathrm{NO}_{3}$ uptake in shallow, oligotrophic, mountain lakes: the influence of elevated NO3 concentrations. J N Am Benthol Soc 23:397-415.

Nydick KR, Lafrancois BM, Baron JS, Johnson BM. 2004b. Nitrogen regulation of algal biomass, productivity, and composition in shallow mountain lakes, Snowy Range, Wyoming, USA. Can J Fish Aquat Sci 61:1256-68.

O'Brien WJ, Barfield M, Bettez N, Hershey AE, Hobbie JE, Kipphut G, Kling G, Miller MC. 2005. Long-term response and recovery to nutrient addition of a partitioned arctic lake. Freshw Biol 50:731-41.

Postgate J. 1998. Nitrogen fixation. Cambridge University Press.

Ramlal PS, Hesslein RH, Hecky RE, Fee EJ, Rudd JWM, Guildford SJ. 1994. The organic-carbon budget of a shallow arctic tundra lake on the Tuktoyaktuk Peninsula, NWT, Canada-Arctic lake carbon budget. Biogeochemistry 24:145-72.

Rosenberger EE, Hampton SE, Fradkin SC, Kennedy BP. 2008. Effects of shoreline development on the nearshore environment in large deep oligotrophic lakes. Freshw Biol 53:1673-91.

Sander R. 1999. Compilation of Henry's law constants for inorganic and organic species of potential importance in environmental chemistry (version 3 ). 
SAS. 2002. [sas/stat] software, version [9.1] of the sas system for [Unix]. Copyright ( 2002-2004, SAS Institute inc. Cary, NC, USA.

Schindler DW. 1977. Evolution of phosphorus limitation in lakes. Science 195:260-2.

Schindler DW, Smol JP. 2006. Cumulative effects of climate warming and other human activities on freshwaters of arctic and subarctic North America. Ambio 35:160-8.

Schindler DW, Hecky RW, Findlay DL, Stainton ML, Parker BR, Peterson MJ, Beaty KG, Lyng M, Kasian SEM. 2008. Eutrophication of lakes cannot be controlled by reducing nitrogen input: results of a 37-year whole-ecosystem experiment. Proc Natl Acad Sci USA 105:11254-8.

Scott JT, Lang DA, King RS, Doyle RD. 2009. Nitrogen fixation and phosphatase activity in periphyton growing on nutrient diffusing substrata: evidence for differential nutrient limitation in stream periphyton. J N Am Benthol Soc 28:57-68.

Sierszen ME, McDonald ME, Jensen DA. 2003. Benthos as the basis for arctic lake food webs. Aquat Ecol 37:437-45.

Smith VH. 1983. Low nitrogen to phosphorus ratios favor dominance by blue-green algae in lake phytoplankton. Science 221:669-71.

Stal LJ, Walsby AE. 2000. Photosynthesis and nitrogen fixation in a cyanobacterial bloom in the Baltic Sea. Eur J Phycol 35:97-108.

Sugai SF, Kipphut GW. 1992. The influence of light and nutrient addition upon the sediment chemistry of iron in an arctic lake. Hydrobiologia 240:91-101.

Vadeboncoeur Y, Lodge DM, Carpenter SR. 2001. Whole-lake fertilization effects on distribution of primary production between benthic and pelagic habitats. Ecology 82:1065-77.
Vadeboncoeur Y, Jeppesen E, Vander Zanden MJ, Schierup HH, Christoffersen K, Lodge DM. 2003. From Greenland to green lakes: cultural eutrophication and the loss of benthic pathways in lakes. Limnol Oceanogr 48:1408-18.

Vadeboncoeur Y, Peterson G, Vander Zanden MJ, Kalff J. 2008. Benthic algal production across lake size gradients: interactions among morphometry, nutrients, and light. Ecology 89:2542-52.

Vander Zanden MJ, Chandra S, Park S-K, Vadeboncoeur Y, Goldman CR. 2006. Efficiencies of benthic and pelagic trophic pathways in a subalpine lake. Can J Fish Aquat Sci 63:260820.

Vitousek PM, Howarth RW. 1991. Nitrogen limitation on land and in the sea: how can it occur? Biogeochemistry 13:87-115.

Vitousek PM, Cassman K, Cleveland C, Crews T, Field CB, Grimm NB, Howarth RW, Marino R, Martinelli L, Rastetter EB, Sprent JI. 2002. Towards an ecological understanding of biological nitrogen fixation. Biogeochemistry 57:1-45.

Webb WL, Newton M, Starr D. 1974. Carbon dioxide exchange of Alnus rubra: a mathematical model. Oecologia 17:281-91.

Wetzel RG. 1964. A comparative-study of the primary productivity of higher aquatic plants, periphyton, and phytoplankton in a large, shallow lake. Int Rev Gesamten Hydrobiol 49:1.

Wetzel RG. 2001. Limnology. Fortworth: Harcourt Brace College Publishers.

Wetzel RG, Likens GE. 1991. Limnological analyses. New York: Springer.

Whalen SC, Cornwell JC. 1985. Nitrogen, phosphorus, and organic carbon cycling in an arctic lake. Can J Fish Aquat Sci 42:797-808. 